\title{
Microbiological Quality Assessment of Hospital Food in a Public Hospital in Fez (Morocco)
}

L. ZBADI ${ }^{1,2}$, A. EL OUALI LALAMI ${ }^{2}$, A. BAROUDI ${ }^{3}$, Z. MARSOU ${ }^{3}$, K. FIKRI BENBRAHIM ${ }^{1 *}$

1- Laboratory of Microbial Biotechnology, Sciences \& Technology Faculty,

Sidi Mohamed Ben Abdellah University, Fez, Morocco.

2- Regional laboratory of Epidemiological Diagnostic and Environment

Hygiene, Regional Health Direction, Fez, Morocco. zbadilat@gmail.com, Eloualilalami@yahoo.fr

3- Health prefectoral Delegation, Regional Health Direction, Fez, Morocco

aminbarou@gmail.com, zakiamarsou@gmail.com

* Corresponding author: Pr. Kawtar FIKRI BENBRAHIM;

(kawtarbenbrahim@hotmail.com; kawtar.fikribenbrahim@usmba.ac.ma)

\begin{abstract}
The food safety has become a major issue in hospitals, since patients are especially vulnerable to foodborne illness considered as nosocomial infection.
\end{abstract}

Aims: Asses food's health hazards in a hospital of Fez city (Morocco).

Material and Results: Hygienic quality of food samples $(n=81$ : meals $(40 \%)$, plants and vegetables $(35 \%)$; meat / meat products $(17 \%))$ and contact surfaces $(n=80$ : local $(32,5 ; \%)$, equipment $(50 \%)$ and staff's hands $(17,5 \%))$ was evaluated during 2011, and involved germs have been researched using standard methods. Results interpreted according to the Moroccan and French standards showed that the percentage of food's non-compliance was $12 \%$, with $32 \%$ for plants / vegetables and $7 \%$ for meat / meat products.

The criminalization of fecal coliform was important (91\%) compared with Staphylococcus aureus (9\%).

Salmonella sp., Listeria monocytogenes, anaerobic sulphito-reducers, yeasts and molds were not implicated.

Contact surfaces analysis showed that $40 \%$ of equipment, $38 \%$ of local and $29 \%$ of the staff's hands were not clean. The causative organisms were fecal coliforms $(60 \%)$ and S. aureus $(40 \%)$.

Conclusion: Contact surfaces may affect the hygienic quality of food served in the hospital. That could make the warning signal in hospitals for the establishment of a global quality policy to ensure food safety and to prevent healthcare associated infections.

\section{Indexing terms/Keywords}

Food safety; Contact surfaces; Quality control; Foodborne illness; Nosocomial infection.

\section{Academic Discipline And Sub-Disciplines}

Food safety.

\section{Subject Classification}

Microbiology.

\section{Type (Method/Approach)}

Quasi-Experimental.

\section{Council for Innovative Research}

\author{
Peer Review Research Publishing System
}

\author{
Journal: JOURNAL OF ADVANCES IN BIOTECHNOLOGY \\ Vol 4, No 1. \\ www.ciribt.org , ibteditor@gmail.com
}




\section{INTRODUCTION}

Availability of healthy and nourishing food is one of the fundamental person's rights and an essential factor for adequate health state [1]. The hospital food service is largely intended for a population with altered defenses towards the infectious processes (immune-incompetent, at extreme age or in long term hospitalization state) which increase the risk and gravity of disease [2]. This risk varies according to numerous parameters as the microorganism's nature, the contamination level, the food nature and especially the consumer's physiological state. Thus, microbiological food contamination through contaminated raw materials, inadequate cooking temperatures, unsuitable conservation, contaminated equipment, cross contamination and personal poor hygiene may be the causes of foodborne illness and / or collective poisoning food [2-3] with serious health, economic and social consequences. In addition, food poisoning represents a real public health problem and is included among the notifiable diseases [4]. Their statement is regulated in Morocco by the Royal decret $\mathrm{N}^{\circ}$. 554-65 of 17 Rabii I 1387 (26 June1967) whose orders and rules are precized in the ministerial decret $\mathrm{N}^{\circ} .683-95$ of 30 Shawwal 1415 (31 March 1995).

Foodbornes illness/ Collective food poisoning represent $11 \%$ of food poisoning and are in over than $90 \%$ cases of confirmed or probable bacterial origin [5]. Therefore, a special attention by hospital managers to food safety in the hospital must be given [6-7]; which requires enhanced health guarantees at all stages from production to distribution [8] to enhance the restoration and protection of patients and caregivers body. Furthermore, knowledge of the microbial ecology of the food environment to identify pathogens and their sources along the food chain, are not well developed and documented even if the role of hospital surfaces in the healthcare associated infections transmission has long been recognized [9]

In this context and to contribute to the improvement of food safety, this work aims to assess the hygienic quality of hospital food and cleanliness of surfaces, equipment and food manipulator's hands, in a public hospital of Fez city (Morocco), to explain the probable contamination causes and to find the potentially dangerous sites where we must carry out corrective actions to prevent occurrence of healthcare associated infections.

\section{MATERIAL AND METHODS}

\section{1- Study Frame}

During 2011, we were interested in controls of microbiological quality for both food and preparation's environment of the meals served to sick people and to the nurse staff. For that purpose, samples were collected from the kitchen of a hospital H1 of Fez city (Morocco). The food microbiological analyzes were performed in the Regional Laboratory of Epidemiological Diagnosis and Environment Hygiene of Fez (RLEDEHF) and the surface's analyzes in the Laboratory of Medical Analyses (L.M.A).

Indeed, in 2011, a total of 17333 patients were registered in complete hospitalization and 2392 in day hospitalization. So, the number of distributed meals was 54180 for the patients and 14100 for the staff, corresponding to a rate of 5690 meals per month (196 meals / day: 158 for the patients and 38 for the staff). It should be noted that the patients numbers are underestimated compared with the average stay duration which was 4.5 in 2011 (ASD=Number of hospitalization days in the year / number admissions or exits + remainders in 01.01) because the meals are not distributed to all of the hospitalized people (the case for example of patients at the maternity department).

\section{2- Sampling}

\section{1- Food Sampling}

Eighty-one food samples from hot and cold dishes were collected from the kitchen of the hospital $\mathrm{H} 1$ just before loading trays in destination to the hospital departments. The frequency of food sampling was twice a month during a period from January to December, 2011 except for the holidays.

\section{2- Surfaces Sampling}

Eighty samples of the kitchen surfaces from the hospital $\mathrm{H} 1$ were collected. According to their nature, there were twentysix samples of local surfaces, forty of materials, and fourteen of the kitchen staff hands (Table 1).

\section{3- Sample Realization}

To guarantee the result's reliability, samples were collected aseptically in hygienic conditions by the same person, according to Le Guyader's instructions [10] for every sample kind (food or surfaces).

Hence, food samples were collected in sterile codified bags, using a sterilized spoon and near the blowtorch, by a technician of the environment hygiene attached to hospital hygiene services. While, surface sampling was performed by the wet swab technique [11] which consists to moisten sterile swab with a sterile isotonic liquid and to take the sample by friction on studied surfaces of locals, equipments and staff's hands.

Then, samples were transported to the laboratory in a cooled icebox maintained at a temperature between 2 and $8^{\circ} \mathrm{C}$. 
Table 1: Non-compliance percentage of the kitchen's surfaces of $\mathrm{H1}$ in 2011

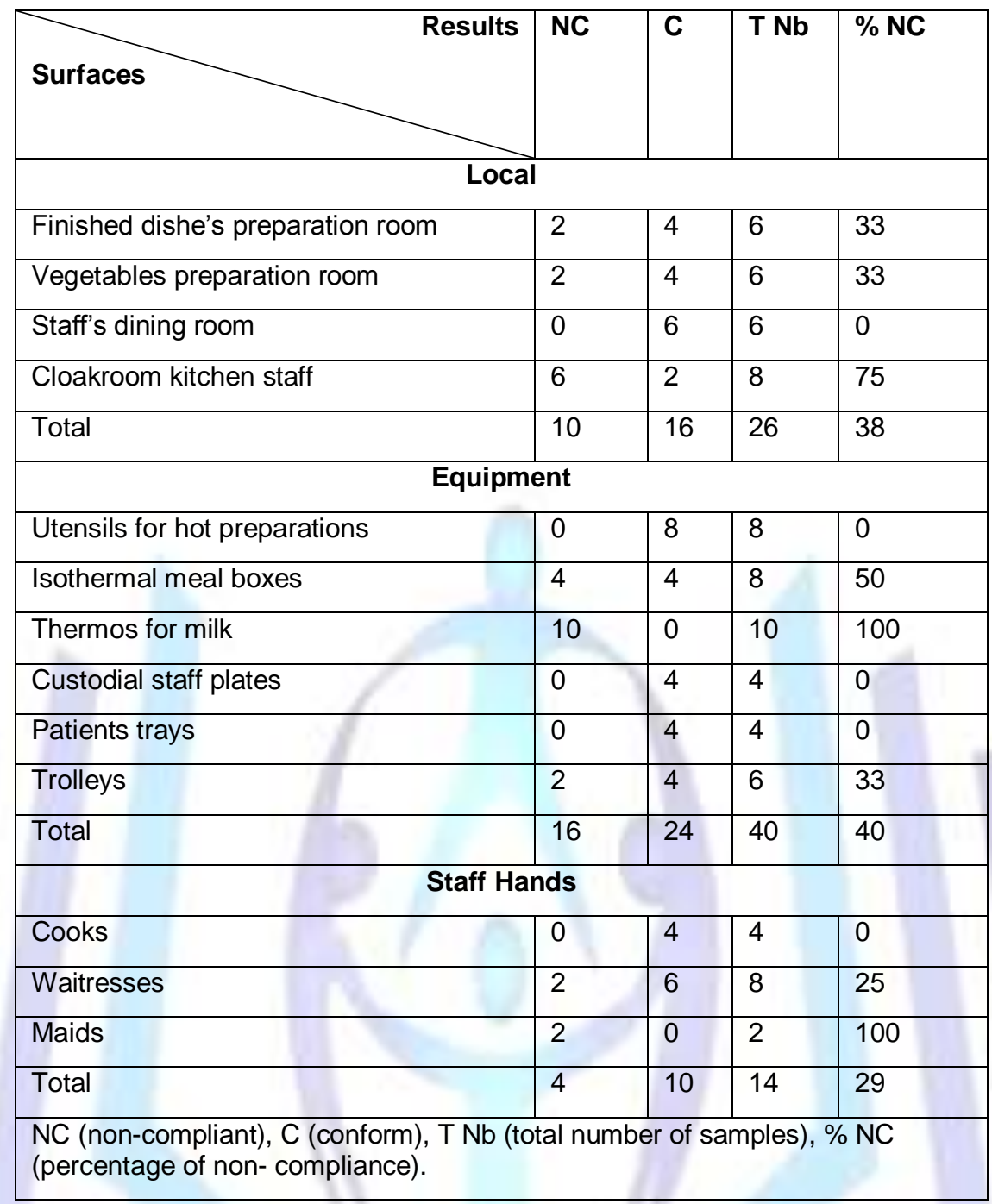

\section{3- Microbiological Analyzes}

Food collected samples were analyzed according to the Moroccan standards (Table 2).

The swabs sampled from surfaces were released in $1 \mathrm{ml}$ of sterile physiological water. Then, this bacterial suspension served as mother solution (MS) to seed the same culture media used for food microbiological analyzes.

\section{4- Result's Interpretations}

Interpretation of the food analyzes results was performed according to Moroccan regulations [12-13], and with reference to French standards [14] for the interpretation of plant products.

While, the criteria for judging the cleanliness of surfaces studied is the presence / absence of pathogenic germs.

\section{5- Statistical Analysis of the Data}

A statistical treatment of food and surfaces analysis results was performed by Microsoft Excel 2013 software.

Yule coefficient $Q$ was calculated to measure the intensity of the relation between the non- compliance and risk foods.

The Chi2 statistical test was performed to determine a relationship between non-compliance and the type of analyzed matrix (food / contact surface). The significance level $p$ was calculated and $P<0.05$ was considered significant. 
Table 2: Process of food's microbiological analyzes

\begin{tabular}{|c|c|c|c|c|}
\hline $\begin{array}{l}\text { Searched } \\
\text { microorganisms }\end{array}$ & Inoculation technique & Culture media & $\begin{array}{l}\text { Incubation } \\
\text { conditions }\end{array}$ & Norms \\
\hline Total germs (TG) & Pour plate technique $(1 \mathrm{ml})$ & Plate Count Agar & $30^{\circ} \mathrm{C} / 24-48 \mathrm{~h}$ & $\begin{array}{l}\text { MN 08.0.121 } \\
\text { (2004) }\end{array}$ \\
\hline $\begin{array}{l}\text { Total } \\
\text { (TC) }\end{array}$ & Pour plate technique $(1 \mathrm{ml})$ & $\begin{array}{l}\text { Desoxycholate Lactose } \\
\text { Agar }\end{array}$ & $30^{\circ} \mathrm{C} / 24-48 \mathrm{~h}$ & $\begin{array}{c}\text { MN ISO } \\
4832(2007) \\
\text { IC. MN } \\
08.0 .115\end{array}$ \\
\hline $\begin{array}{l}\text { Fecal coliform } \\
\text { (FC) }\end{array}$ & Pour plate technique $(1 \mathrm{ml})$ & $\begin{array}{l}\text { Desoxycholate Lactose } \\
\text { Agar }\end{array}$ & $44^{\circ} \mathrm{C} / 24-48 \mathrm{~h}$ & $\begin{array}{c}\text { MN 08.0.124 } \\
(2004)\end{array}$ \\
\hline $\begin{array}{l}\text { Staphylococcus } \\
\text { aureus } \\
\text { (S. aureus) }\end{array}$ & $\begin{array}{l}\text { Spread plate technique }(0,1 \\
\mathrm{ml})\end{array}$ & $\begin{array}{l}\text { Selective medium Baird } \\
\text { Parker }\end{array}$ & $37^{\circ} \mathrm{C} / 24-48 \mathrm{~h}$ & $\begin{array}{c}\text { MN ISO } \\
6888 \text { (2002) } \\
\text { IC.MN } \\
08.0 .104\end{array}$ \\
\hline $\begin{array}{l}\text { Salmonella sp } \\
\text { (Salm) }\end{array}$ & $\begin{array}{l}\text { * Pre-enrichment } \\
(25 \mathrm{~g} \text { of food). } \\
\text { * Enrichment ( } 0.1 \mathrm{ml} \text { of the } \\
\text { mother solution MS) } \\
\text { * Isolation : by streaking } \\
\text { *Identification }\end{array}$ & $\begin{array}{l}\text { *Peptone Water (225 ml) } \\
\text { * Visilliadis Rappaport } \\
\text { Broth (10ml). } \\
\text { * Hektoen. } \\
\text { * Api 20E Gallery }\end{array}$ & $\begin{array}{l}37^{\circ} \mathrm{C} / 24 \mathrm{~h} \\
44^{\circ} \mathrm{C} / 24 \mathrm{~h} \\
24 \mathrm{~h} / 37^{\circ} \mathrm{C} \\
24-48 \mathrm{~h} / 37^{\circ} \mathrm{C}\end{array}$ & $\begin{array}{c}\text { MN 08.0.116 } \\
(2004)\end{array}$ \\
\hline $\begin{array}{l}\text { Anaerobic } \\
\text { Sulphite- } \\
\text { reducers (ASR) }\end{array}$ & Pour plate technique $(1 \mathrm{ml})$ & $\begin{array}{l}\text { Sodium sulfite agar - } \\
\text { Sulfite Polymyxin Cystein } \\
(20 \mathrm{ml}) \text {. }\end{array}$ & $24-48 \mathrm{~h} / 37^{\circ} \mathrm{C}$ & $\begin{array}{l}\text { MN 08.0.125 } \\
(2004)\end{array}$ \\
\hline $\begin{array}{l}\text { Listeria } \\
\text { monocytogenes } \\
\text { (L.m) }\end{array}$ & $\begin{array}{l}\text { * Pre-enrichment }(25 \mathrm{~g} \text { of } \\
\text { food) } \\
\text { * Enrichment: (1 } \mathrm{ml} \text { of } \\
\text { solution) } \\
\text { * Isolation: by streaking } \\
\text { technique }\end{array}$ & $\begin{array}{l}\text { *Frazer half Broth } \\
(225 \mathrm{ml}) \\
\text { * Frazer Broth } \\
\text { * PALCAM } \\
\text { * Trypton Soya Yeast } \\
\text { Extract (TSYAE) }\end{array}$ & $\begin{array}{l}30^{\circ} \mathrm{C} / 24 \mathrm{~h} \\
37^{\circ} \mathrm{C} / 48 \mathrm{~h} \\
37^{\circ} \mathrm{C} / 24 \mathrm{~h} \\
37^{\circ} \mathrm{C} / 24 \mathrm{~h}\end{array}$ & $\begin{array}{c}\text { MN 08.0.110 } \\
(2006)\end{array}$ \\
\hline $\begin{array}{l}\text { Yeast and } \\
\text { mold }\end{array}$ & $\begin{array}{l}\text { Spread plate technique }(0,1 \\
\text { ml) }\end{array}$ & $\begin{array}{l}\text { Sabouraud agar medium } \\
\text { Chloramphenicol Agar } \\
\text { medium (1ml) }\end{array}$ & $25^{\circ} \mathrm{C} / 24-72 \mathrm{~h}$ & $\begin{array}{l}\text { MN } 08.0 .123 \\
(2004)\end{array}$ \\
\hline
\end{tabular}

\section{RESULTS}

Eighty-one food samples from the kitchen of the hospital $\mathrm{H} 1$ and eighty surfaces samples of places, equipment and staff hands of the same kitchen were analyzed in 2011 in the RLEDEHF and LAM laboratories respectively.

\section{1- Distribution of Samples According to their Categories}

\section{1- Food}

The food samples received at the laboratory were composed, in decreasing order, of meals $(n=32 ; 40 \%)$, plants and vegetables $(n=28 ; 35 \%)$, meat and meat products $(n=14 ; 17 \%)$, fish and sea products $(n=5 ; 6 \%)$ and pastries $(n=2$; $2 \%$ ). While milk and dairy products, egg products and preserves were not sampled (Figure 1). 


\section{2-Surfaces}

Surface samples were composed of 40 equipment samples (50\%), 14 staff hand's samples (17\%) and 26 local's samples (33\%) of the hospital H1 kitchen (Figure 2).

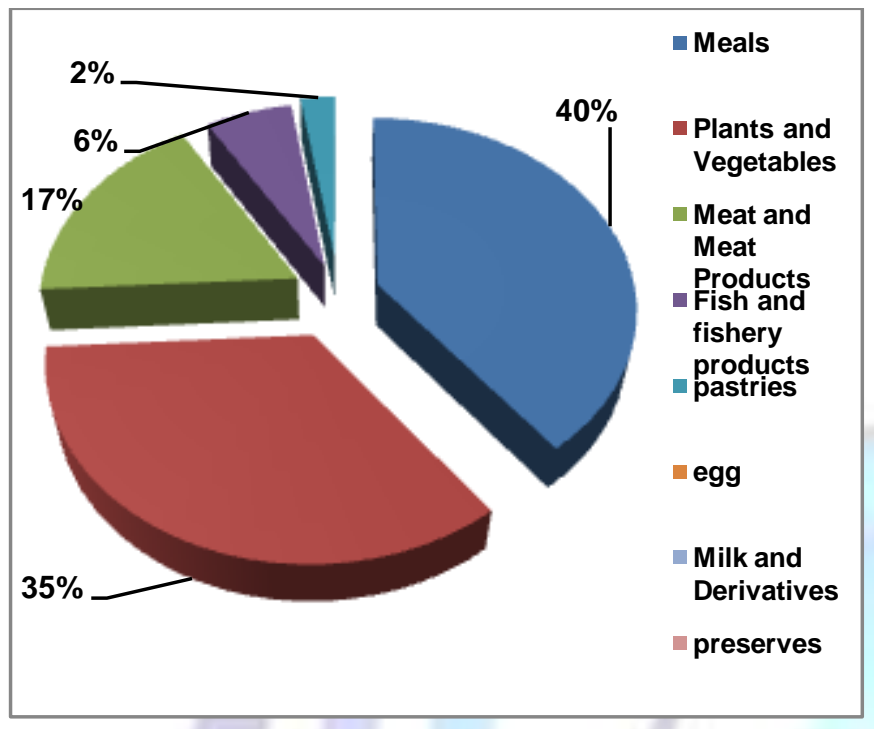

Fig. 1: Distribution of food samples according to their Categories

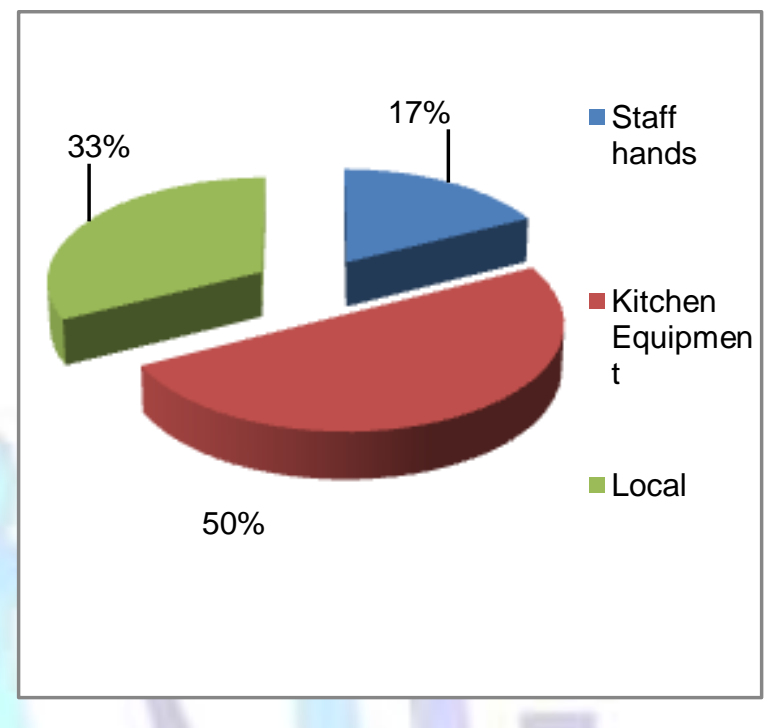

Fig. 2: Distribution of surface sampled according to their nature

\section{2- Microbiological Quality of Samples Analyzed in 2011}

\subsection{Total Non-Compliance Registered in 2011}

From 81 food samples analyzed in 2011, ten were contaminated with a global percentage of non-compliance (NC) of $12 \%$. Among 80 surfaces samples studied, 30 sites were not clean, corresponding to a total NC percentage of $37 \%$ (Figure 3 ).

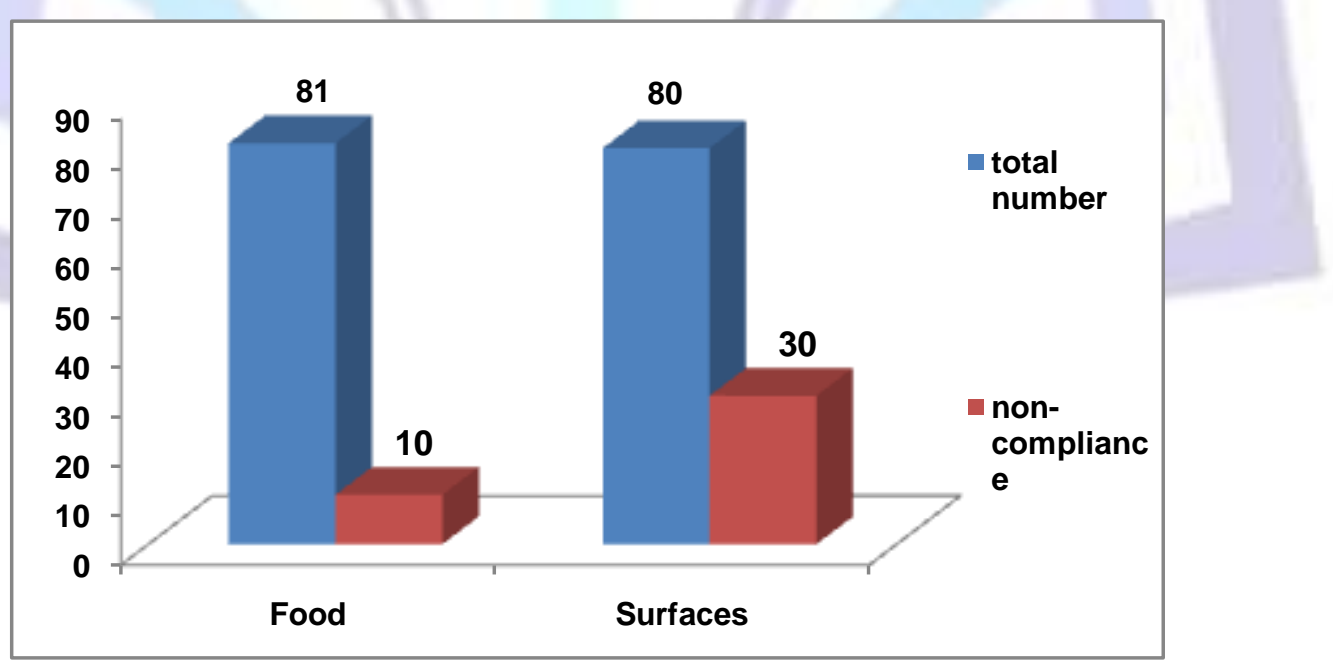

Fig. 3: Global non-compliance of food samples and contact surfaces recorded in 2011

\subsection{Non-compliance According to the Nature of Food and Surfaces Analyzed in 2011}

\section{- According to the Food Category}

All food's classes analyzed in 2011 were in good hygienic conditions, except the class of plants and vegetables where the percentage of NC was $32 \%$ and that of meat / meat products which was contaminated in $7 \%$ of cases. 


\section{- According to the Surfaces Nature}

The NC percentage of surfaces studied in 2011 was, in decreasing order, $40 \%$ for equipment, $38 \%$ for local and $29 \%$ for the kitchen staff's hands (Table 1).

\subsection{Non-Compliance According to Germs Responsible for Food's and Surface's Contamination}

\section{- Involvement of Germs in the Analyzed Food Non-Compliance}

Fecal coliform (FC) have been implicated in $82 \% \mathrm{NC}(\mathrm{n}=9)$ of plant / vegetables and $9 \% \mathrm{NC}(\mathrm{n}=1)$ of meat $/$ meat products. While Staphylococcus aureus (S. aureus) were involved only in $9 \%(n=1)$ of plants and vegetable's NC. All the other food categories were compliant and no germs; Listeria monocytogenes, Salmonella sp., Anaerobic - sufito -reducers, yeasts and molds and total germs, have been implicated (Figure 4).

\section{- Involvement of Germs in the Non Compliance of the Studied Surfaces}

Fecal coliforms (FC) and Staphylococcus aureus have been incriminated in the NC of studied surfaces for $n=18$ ( $60 \%$ ) and $n=12(40 \%)$ respectively. So, FC were abundantly found on equipments $n=16(40 \%)$ (All milk thermos $(n=10)$, half of the meal boxes $(n=4)$ and a third of trolleys $(n=2)$, FC were also isolated from locals $(n=2 ; 8 \%)$ (vegetable's processing room $(\mathrm{n}=2))$.

While $S$. aureus were isolated from locals $(n=8,31 \%)$, (especially from the staff cloakrooms $(n=6)$, but also from the finished dishes preparation room $(n=2), S$. aureus were also detected on the staff hands $(n=4,29 \%)$ (All house keeper's hands $(n=2)$ and a quarter of the waitresses $(n=2))$.

While no Salmonella sp. has been identified on studied surfaces during the year 2011, we also noted the absence of pathogenic germs on the cookers hands (Table1; Figure 5).

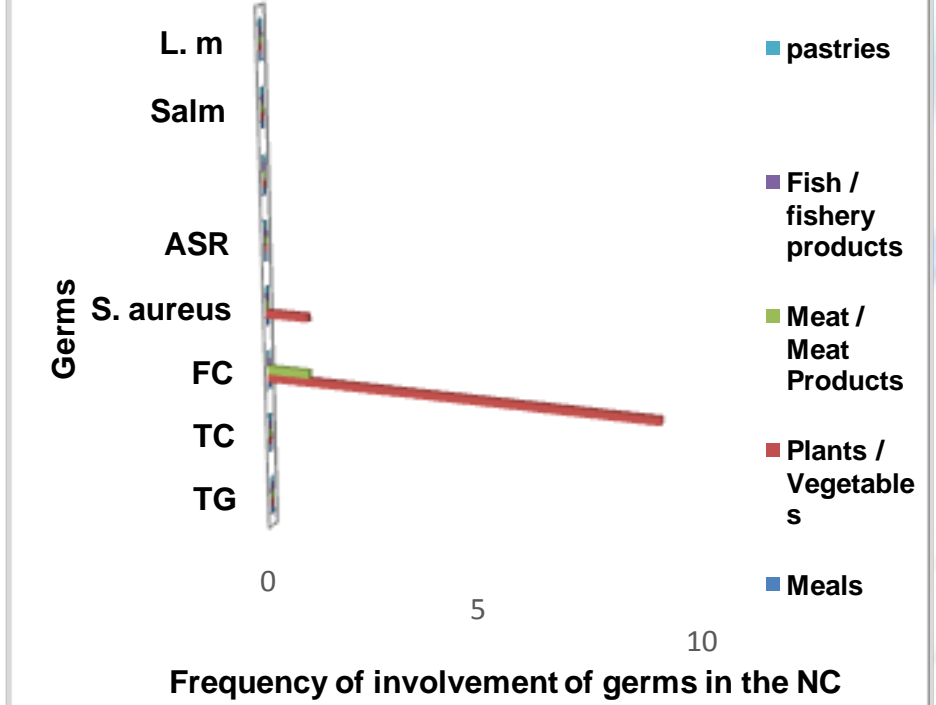

Fig. 4: Involvement of germs in the analyzed food noncompliance

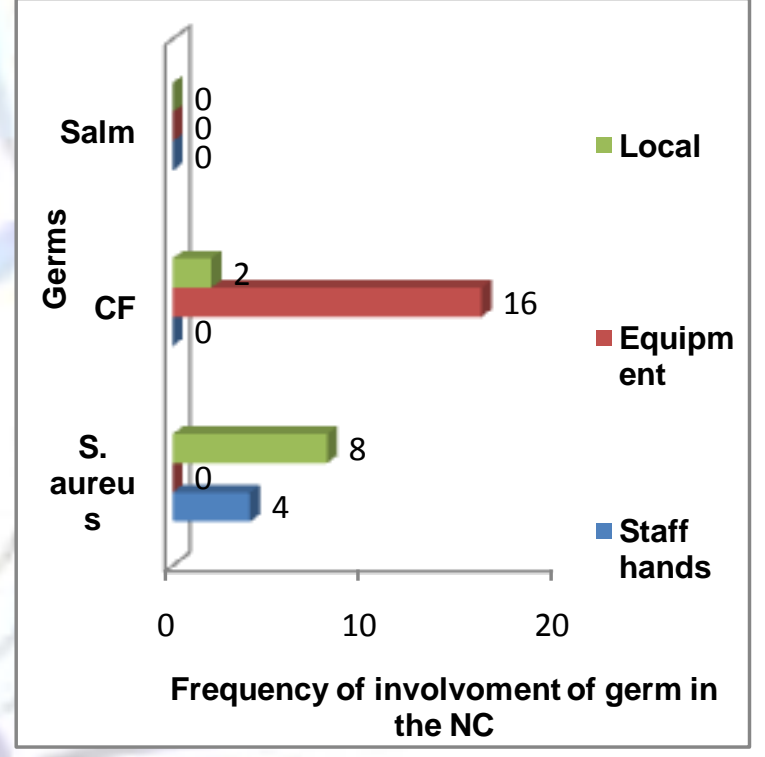

Fig. 5: Involvement of germs in the analyzed surfaces non-compliance

TG (Total Germs), TC (Total Coliform), FC (Fecal coliform), S. aureus (Staphylococcus aureus), ASR (Anaerobic sulphito-reducers), Salm (Salmonella sp.), Lm (Listeria monocytogenes).

\section{3 - Statistical Tests}

The $Q$ coefficient of $Y u$ calculated for the two variables studied which are food categories (plants and vegetables; meat and meat products) and their non-compliance rate was 0.72 .

The Khi2 calculated value (13.64) is greater than the Khi2 table value (3.84) at the risk $\alpha=5 \%$ and the degree of freedom $\mathrm{df}=1$. The test is very significant with a $\mathrm{p}$ - value $=0.00022<0.05$. 


\section{DISCUSSION}

The number of food samples collected in this study ( $\mathrm{n}=81$ or 6.8 samples per month) was more representative than that reported in a 10 years retrospective study evaluating the food microbiological quality in the same establishment $\mathrm{H} 1$ ( $\mathrm{n}=107$ in 10 years or 10.7 samples per year and 0.9 per month) [7]. This could be explained by an increase of the hospital hygiene services aware to the importance of regular monitoring of food served to patients. It could also contribute to estimate better the food related infection risk and therefore prevent foodborne illness / collective food poisoning especially among weakened populations.

Thus, the food samples received and analyzed were composed predominantly by meals (40\%), plants and vegetables (35\%) and meat and meat products (17\%). Moreover, the categorization of foods allowed us to recognize risky foods with a particular danger to vulnerable people and so to grant them a particular attention. Therefore, the food served in the establishments of health should be carefully chosen and must undergo frequent checks to minimize the risk of foodborne illness according to Lund and O'Brien [15].

Microbiological analyzes results of the different food categories showed that plants and vegetables class was the most contaminated one (32\%). This percentage is similar to that found by Aycicek et al. [16] (31.4\%). While other studies reported high rates of contamination in salads [17-18]. Moreover, the rate of non-compliance in meat was low (7\%) compared to $33 \%$ obtained by Abouda et al. [19] in a Tunisian study on meat / meat products used in hospital catering. These findings indicate a potential risk of hospital patient's poisoning linked to the consumption of plants / vegetables or crude salads in particular and also meat / meat products. Indeed, the statistical test $Q$ has proved that the relationship between the food risk and the $\mathrm{NC}$ is very high $(0.70<\mathrm{Q}<1)$.

Furthermore, no non-compliance has been recorded for other food categories especially prepared meals (40\%) or fish and sea products $(6 \%)$ which might be, according to the Moroccan culinary habits, submitted to a sufficient cooking time for the destruction of pathogenic microorganisms. In this sense, Langlois and al. [20] insisted on the food's heat treatment to prevent foodborne illness related to food consumption. However, these foods types could present a poisoning danger for fragile patients even at low germs concentrations because the standards of interpretation of these foods are not adapted to this type of consumer.

The global non-compliance obtained for analyzed food (12\%) was much higher than $3.3 \%$ found by Little et al. [21] However, it was relatively lower than those reported by several other authors [22-23-24], which are respectively about 17.1 $\% ; 18.8 \%$ and $15 \%$ as well as than the average rate registered for the same hospital $\mathrm{H} 1$ during period 2001-2010 (18.7\%) [7]. This decrease could be due to succeeded actions after the creation of the Committee of Fight against Healthcare associated infections in 2009 during the accreditation project of the studied hospital, besides the creation of a service of working medicine that requires regular medical tests (coprocultures, parasitology of saddles) for the kitchen staff. However, this rate remains high looking to singularity and particularity of the hospital guests, which would require continuous efforts of food safety.

The implication of fecal coliforms in the majority of analyzed food's contamination cases (91\%) was consistent with the results of Loiseau-Marolleau and Laforest [18] that showed the dominance of $E$. coli among enterobacterieaceae, in 194 hospital food samples. Indeed, fecal coliforms are represented to 95-99\% by Escherichia coli [25] which pathogenic strains are grouped into pathovars whose each one is associated with a characteristic infectious syndrome causing foodborne illness in hospital environment with dramatic consequences. Thus, enterohemorrhagic E. coli Shiga toxin producers, especially serotype 0157: H7 has been involved in several foodborne outbreaks [26-3] with low infectious doses [27].

Moreover, the great contamination of plants / vegetables class by fecal coliforms (82\%) is consistent with the results of a previous study which showed that $93 \%$ of salads presented fecal contamination [17], but much higher than that found by Aycicek et al.[16] (11.4\% in salads). This could be related to the water quality used for irrigation, or the crosscontaminations or recontaminations phenomena during the preparation steps of this food category or to the absence of heat treatment of crude consumed food.

While the percentage of meat / meat products contamination by fecal coliforms (CF) was low (9\%), although it has been reported that $E$. colican be present in foods of animal origins, such as beef, pork and poultry [26-28].

So, salads and cooked meat products may be contaminated with E.coli if the production practices of the crude material, handling procedures, processing treatments and/or storage conditions are not appropriate [26]. This can be serious because $E$. coli has been recognized as a microbiological hazard in these foods types [15-26-29-28].

Furthermore, S. aureus, often recognized responsible of food poisoning [30-31], associated with dairy products or dishes having been largely manipulated (mixed salads) was involved only in $9 \%$ of food NC in this study, especially for plants and vegetables category. This percentage is close to that obtained by Aycicek et al. [16] in salads (11.4\%). The contamination could be of human origin through hand carriage or healthy carriers (nasopharyngeal carriage) [16] which may reflect cross-contamination and/or recontamination [32-33].

The absence of pathogen germs (L. monocytogenes, Salmonella sp., Anaerobic sulfito reducers, yeasts and molds) in our samples is in agreement with results observed by Aycicek et al. [16] who have not detected any Salmonella sp. nor Clostridium perfringens in salads and dishes and with those reported by Rodriguez et al. [33] who showed the absence of L. monocytogenes and Salmonella sp. in lettuce salads and cooked ham. While several foodborne outbreaks due to Salmonella sp., Clostridium perfringens and L. monocytogenes have been reported in hospitals [34-35-36-3]. Thus, 
specific and strict measures must be undertaken to avoid contamination of culinary preparations served to vulnerable consumers.

The method 5M inspired from Ishikawa diagram cause-effect (Figure 6) shows that the raw material (Food), hardware (equipment), the environment (local), the method (processes and procedures) and labor (staff) are the main risk factors that may contaminate food and cause foodborne illness [6]. Reliable and comprehensive risk assessment of food contamination seems mandatory to ensure optimum food safety [37].

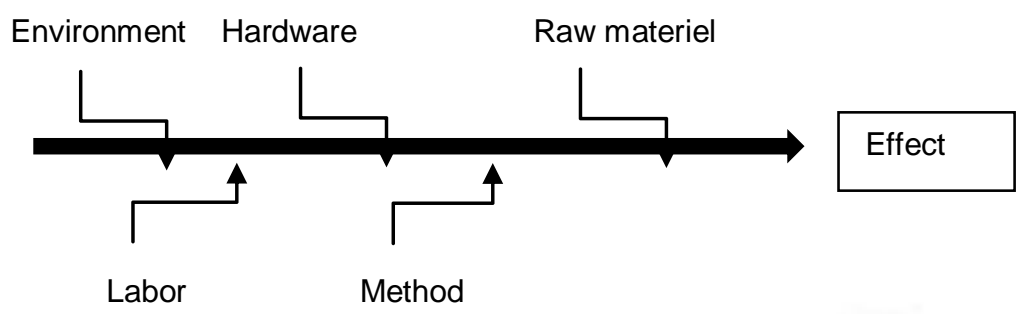

Fig. 6: Ishikawa diagram cause-effect

Results of surface's microbiological monitoring ( $40 \% \mathrm{NC}$ for equipment, $38 \%$ for local and $29 \%$ for the kitchen staff's hands) are consistent with those reported by Abouda et al. [19] (28\% NC for equipment, $35 \%$ NC for local and $31 \%$ NC for the food manipulators hands.

Other studies also showed that food handlers, utensils and / or work surfaces are potential sources of bacterial contamination [38-39].

This could be explained by the residential architecture of the hospital (contamination of locker room exposed to the external environment), the architectural conception of the kitchen, which does not respect the forward motion's circuit (contamination of vegetables and finished dishes treatment room). Also, by using inadequate equipment (hard to clean utensils; like milk thermos) or not regularly cleaned (like the food supports) and by the carelessness or ignorance of good hygiene practices by of all food handlers throughout the food chain (waitresses, maids and women of loads whose academic standard is low).

Fecal coliforms were responsible of most NC cases found in the studied surfaces $(100 \%$ NC in equipment and $20 \%$ NC in local), which is in agreement with results obtained by Monge et al. and Gikas et al. [17-40]. This could be related to bad hygienic equipment conception and / or to inefficient cleaning procedures. Indeed, previous studies emphasized the interest of selection and validation of equipment easy to clean and improvement of cleaning and disinfection procedures) [41-35-42]. However, the absence of fecal coliforms in staff hand's samples is discordant with other previous works [1743-44].

Results of surfaces colonization by staphylococci (31\% NC in local and $29 \%$ NC in the staff hands) are in agreement with those of Fagernes and Lingaas and Jiménez et al. [44-43] who detected S. aureus on $25.8 \%$ and $69 \%$ of the staff hands respectively. This suspects their role in cross contaminations and food poisoning which have been highlighted by Gikas et al.; Perez-Rodriguez et al.; Ewen \& Todd [40-45-46]. So it will be very important to improve the level of food handler's hygiene and to take more precautions to avoid cross-contamination in hospital kitchens.

The absence of Salmonella sp. in the various analyzed surfaces samples is coherent with the conclusions of Gikas et al. [40] that showed the absence of Salmonella enteridis in samples collected from inert surfaces and utensils. Eventhough, the risk of Samonella sp. transmission through the food chain cannot be neglected due to its capacity to colonize inert surfaces in contact with food, to form biofilms [47-48] and its easy transfer from the kitchen equipments to food [41].

The absence of pathogenic germs (S. aureus, FC, Salmonella sp.) on the cookers hands and utensils (custodial staff Plates and Patients trays) could be related respectively to the cooker's hygiene professional trainings level and to efficient methods / ease of washing utensils with soap and hot water according to Ravishankar et al. [41].

These results highlight the importance of food's manipulators regular control and their regular and repetitive training on hygienic practices on one hand, the necessity of hygienic equipment's conception and their cleaning procedures improvement and kitchen's management amelioration on the other hand.

Fecal coliforms and $S$. aureus were responsible for the food NC and were also isolated from the studied surfaces, which suspect the existence of a causal relationship between food and surfaces NC. Moreover, the Khi ${ }^{2}$ independence test was highly significant $(p<0.001)$ showing that the global non-compliance rate depends strongly on the analyzed matrix (food / surfaces).

These results are concomitant with previous funding which proved that pathogenic agents $(S$. aureus, E. coli and Salmonella sp.) can be transferred from contaminated food to hands and contact areas [49-41] and inversely from surfaces to foods [32-50]. A molecular identification and an antibiogram achievement for the strains isolated from surfaces and foods is necessary to confirm the germs transfer possibility. 
It should be noted that no preliminary study has been published on the assessment of the microbiological quality of food and contact surfaces in Fez hospital kitchens (Morocco). The realization of such monitoring is justified by its epidemiological interest for hospital administrators to analyze the incurred risks in the kitchen and find appropriate solutions and by its educational interest to the staff of hospital kitchens. So, later studies more detailed on this subject should be conducted in Moroccan hospitals.

\section{CONCLUSIONS}

This study investigated the microbiological control of food and kitchen surfaces of a hospital H1 of Fez city in 2011 to assess the hygienic quality of food and target potential germs survival locations where corrective actions should be carried out to prevent the occurrence of healthcare associated infections and therefore of foodborne illness.

Results showed that the overall food's non-compliance rate was $12 \%$, with a great contamination average for plants and vegetables (32\%) and only $7 \%$ for meat / meat products. Thus, food categories must undergo frequent checks to minimize the risk of foodborne illness. The studied surface's non-compliance was as high for equipment (40\%) as for locals (38\%) and kitchen staff's hands (29\%). The incriminated germs were fecal coliform and S. aureus for both contact surfaces and food. This show cross-contamination and recontaminations due to a lack of food handler's hygiene and to a bad hygienic design of kitchen's equipment in the studied hospital.

Therefore, the improvement of food safety requires risk control and rigorous application of the hygienic rules. To achieve this goal, it is necessary to ameliorate local's management, to have hygienic equipment's design and efficient cleaning procedures, to ensure a regular medical control for the kitchen's staff, guarantee its training and repeated training on good hygienic practices throughout the food chain on one hand. To establish an adequate HACCP system for effective environmental monitoring plans and epidemiological investigations and to create a structure for coordination and evaluation of the all of the involved actor's actions (LFNC: Liaison Food Nutrition Committee) on the other hand.

\section{ACKNOWLEDGMENTS}

The authors wish to thank Pr. L. Bennani, from the Training Institute for Health Care Careers; Ms. S. Berrada, LRDEHMF, $\mathrm{Mr} \mathrm{H}$. Sabrei, head nurse of the LRDEHMF; Mr H. Zbaa, head nurse of the LMA in Fez; Mr A. Chadli, responsible for the provincial hygiene office, Ms M. Ftouhi, lab technician of environment hygiene at the health Delegation in Fez, Dr. S. Maniar of regional observatory at the Health Regional Directorate of Fez and every person who contributed to this work.

\section{Competing of Interest}

The author(s) declare that they have no competing interests.

\section{REFERENCES}

[1] FAO/OMS. (2005). L'impact sur la santé humaine des systèmes de sécurité sanitaire des aliments établis au ProcheOrient. Réunion régionale pour le Proche-Orient sur la sécurité sanitaire des aliments. Amman, Jordanie. (NEM 05/3).

[2] Custovic, A., \& Ibrahimagic, O. (2005). Prevention of food poisoning in hospitals. Medicinskiarhiv, 9 (5), $303-305$.

[3] Lund, B. M. \& O'Brien, S. J. (2014). Public Health Measures: Food Safety in Hospitals and other Healthcare Settings. Encyclopedia of Food Safety, 140-148.

[4] Bouharrass, A., Akrim, M., Ezzahidi, A., Fathi, R., Oudghiri, M., Maaroufi, A., \& Barkia A. (2012). Investigation d'un épisode de TIAC à l'Institut Agronomique et Vétérinaire D'AIT MELLOUL. Bulletin Epidémiologique.

[5] Benkaddour, K. (2002). Situation épidémiologique des toxi-infections alimentaires collectives au Maroc, $19--2001$. Séminaire national sur l'application du système HACCP dans le domaine de l'hygiène alimentaire. Ministère de la santé. Rabat.

[6] Cosson, C., Bolnot, F. H., \& Tronchon P. (2003). « Sécurité alimentaire » en milieu hospitalier : de la logique de crise à la logique de progrès. Nutr. Clin. Metab, 17, 242-517.

[7] Zbadi, L., Fikri Benbrahim, K., Bennani, L., Berrada, S., Maniar, S., El Ouali Lalami A. 2014. Evaluation de la qualité microbiologique des aliments en milieu hospitalier : «bilan de dix ans ». Nutrition Clinique et Métabolique, $\mathrm{N}^{\circ}$ NUTCLID-

[8] Bolnot, F. H., et Carlier, V. (2000). "Sécurité des Aliments : du risque à la crise". Bulletin de la Société Vétérinaire Pratique de France.

[9] Setlhare, G.G., Malebo, N.J., Shale, K., and Lues, J. F. R. (2013). Microbial levels on the food preparation areas of a typical district hospital in South Africa. African Journal of Microbiology, Vol. 7(24), 2998-3008.

[10] Le Guyader, A. (1999). Recommandations pour les contrôles d'environnement dans les établissements de santé. C. CLIN-Ouest.

[11] Lebreton, V., Simon, L., Leistreit, J.M., and May, I. (1998). Assurance qualité des préparations stériles : évaluation des techniques des prélèvements microbiologiques sur des surfaces. Journal de Pharmacie Clinique, 17, $227-31$. 
[12] Anonymous (2004). Normes microbiologiques auxquelles doivent répondre les denrées animales ou d'origine animale : Arrêté conjoint du ministère de l'agriculture et du développement rural, du ministère de la santé et du ministère de l'industrie, du commerce et des télécommunications n¹737-02, Bulletin Officiel N5214, Maroc.

[13] Ministère de la santé (1997). Manuel de Microbiologie alimentaire, Institut National d'Hygiène. Rabat, Maroc

[14] Larpent, J. P. (1997). Microbiologie Alimentaire : Technique de laboratoire, Technique et documentation. Londres, New York, Paris, Lavoisier.

[15] Lund, M. B., O'Brien, J. S. (2009). Microbiological safety of food in hospitals and other healthcare settings. Journal of Hospital Infection, 73, 109-120.

[16] Ayçıçek, H., Sarimehmetoglu, B., Çakiroglu, S. (2004). Assessment of the microbiological quality of meals sampled at the meal serving units of a military hospital in Ankara, Turkey. Food Control, 15, 379-384.

[17] Monge, R., Arias, M. L., Utzinger, D., Antillón, F. (1994). Sanitary quality of some food distributed by hospital food services of Costa Rica. Arch Latinoam Nutr. 44(3), 164-167.

[18] Loiseau-Marolleau, M. L., Laforest, H. (1976). Contribution à l'étude de la flore bactérienne des aliments en milieu hospitalier. Médecine et Maladies Infectieuses, 6 (5), 160-171.

[19] Abouda, Y., Nouira, A., Njah, M. (2007). Risque microbiologique associé à la chaîne de préparation des viandes et autres produits carnés utilisés en restauration hospitalière au CHU F. Hached de Sousse. Microbiol. Hyg. Alim., 19 (54), 30-35.

[20] Langlois, B. E., Bastin, S., Akers, K., and O'Leary, J. (1997). Microbial quality of foods produced by an enhanced cook-chill system in a hospital. Journal of Food Protection, 60, 655-666.

[21] Little, C. L., Barrett, N. J., Grant, K., McLauchlin, J. (2008). Microbiological safety of sandwiches from hospitals and other health care establishments in the United Kingdom with a focus on Listeria monocytogenes and other Listeria species. Pathol Biol., 56 (5), 272-8.

[22] Lejeune, B., Poinsignon, M., Leroux, N., et Lebras, M.P. (1988). L'hygiène alimentaire en cuisine hospitalière : Bilan de trois années de surveillance microbiologique. Médecine et Maladies Infectieuses, 110-114.

[23] Majjou, M. (2006). Etude de la sécurité du circuit alimentaire dans les hôpitaux, Cas de l'hôpital Ibn Sina de Rabat. Mémoire. Institut de Formation aux Carrières de Santé, Rabat, Maroc.

[24] Abouda, Y., Bouafia, N., Mzoughi, R., Houij, H., Njah, M. (2011). La qualité bactériologique en restauration hospitalière : un paramètre de gestion de risque infectieux. ScienceLib $3, N^{\circ} 110301$.

[25] Rosset, F., Beaufort, A. (1983). Nature et description des intoxications alimentaires :"La restauration sociale et commerciale". Paris: I.S.T.V. 339-47.

[26] Valero, A., Rodríguez, M., Carrasco, E., Pérez-Rodríguez, F., García-Gimeno, R.M., Zurera G. (2010). Studying the growth boundary and subsequent time to growth of pathogenic Escherichia coli serotypes by turbidity measurements. Food Microbiology, 27, 819-828.

[27] Strachan, N. J. C., MacRae, M., Ogden, I. D. (2005). Quantifying the Escherichia coli O157 reservoir in Grampian, Scotland. Vet. Rec., 156, 282-283.

[28] Barka, M. S., (2011). Recherche et caractérisation d'Escherichia coli entérohémorragique O157 : H7 dans les viandes bovines importés en Algérie. Thèse. Université d'Oran.

[29] Berger, C. N., Sodha, S. V., Shaw, R. K., Griffin, P. M., Pink, D., Hand, P., and Frankel, G. (2010). Fresh fruit and vegetables as vehicles for the transmission of human pathogens. Environmental Microbiology, 12(9), $2385-2397$.

[30] Ouahid, M. (1993). Toxi-infections alimentaires et hygiène de certaines préparations culinaires au Maroc. Thèse, Université de Clermont-Ferrand 2, France.

[31] Belomaria, M., Ahami, A. O. T., Aboussaleh, Y., Elbouhali, B., Cherrah, Y., et Soulaymani, A. (2007). Origine environnementale des intoxications alimentaires collectives au Maroc : Cas de la région du Gharb Chrarda Bni Hssen. Antropo., 14, 83-88.

[32] Pérez-Rodríguez, F., Valero, A., Todd, E.C.D., Carrasco, E., García-Gimeno, R.M.,Zurera G. (2007). Modeling transfer of Escherichia coli O157:H7 and Staphylococcus aureus during slicing of a cooked meat product. Meat Science, 76, 692-699.

[33] Rodriguez, M., Valero, A., Carrasco, E., Pérez-Rodríguez, F., Posada, G.D., Zurera, G. (2011). Hygienic conditions and microbiological status of chilled Ready-To-Eat products served in Southern Spanish hospitals. Food Control, 22 (6), 874-882.

[34] Lingaas, E., Johnsen, B.O., Torfoss, D., D. H. Dorenberg, Andersen, C. T., Müller, F., et al. (2008). Listeria monocytogenes outbreak in a comprehensive cancer and transplantation center. In 18th European Congress of Clinical Microbiology and Infectious Diseases, Barcelona, Spain, 19-22 April, Presentation O44. 
[35] Carrasco, E., Morales-Rueda, A., García-Gimeno, R. M. (2012). Cross-contamination and recontamination by Salmonella in foods. Food Research International, 45545-556.

[36] Lahou, E., Jacxsens, L., Verbunt, E., Uyttendaele. M. (2013). Evaluation of the food safety management system in a hospital food service operation toward Listeria monocytogenes. Food Control, http://dx.doi.org/10.1016/j.foodcont.2013.10.020

[37] Bolnot, F. H., Benet, J. J. (2000). Sécurité des aliments : maîtrise des risques, prévention des crises. Bull Soc Vet Prat de France, 84 (4), 231-48.

[38] Christison, C. A., Lindsay, D., \& Von Holy., A. (2007). Cleaning and handling implements as potential reservoirs for bacterial contamination of some ready-to-eat foods in retail delicatessen environments. Journal of Food Protection, 70, 2878-2883.

[39] Naidoo, K., \& Lindsay,D. (2010). Potential cross-contamination of the ready-to-eat dried meat product, biltong. British Food Journal, 112, 350-363.

[40] Gikas, E.I., Kritsotakis, S., Maraki, M., Roumbelaki, D., Babalis, E., Scoulica, C., Panoulis, Saloustros, E., Kontopodis, E., Samonis, G., Tselentis, Y.A. (2007). Nosocomial, foodborne outbreak of Salmonella entericaserovar Enteritidis in a University hospital in Greece: the importance of establishing HACCP systems in hospital catering. Journal of Hospital Infection, 66, 194-196.

[41] Ravishankar, S., Zhu, L., \& Jaroni, D. (2010). Assessing the cross contamination and transfer rates of Salmonella enterica from chicken to lettuce under different food handling scenarios. Food microbiology, 27, 791-794.

[42] Campdepadrós, M., Stchigel, A. M., Romeu, M., Quilez, J., Solà, R. (2012). Effectiveness of two sanitation procedures for decreasing the microbial contamination levels (including Listeria monocytogenes) on food contact and non-food contact surfaces in a dessert-processing factory. Food Control, 23(1), 26-31.

[43] Jiménez, F., Garro, L., Rodríguez, E., Zeledón, Z. (2005). Evaluation of the presence of bacteria in food and environment of an Oncological Service of a National Hospital, San José, Costa Rica. J Hosp Infect, 59 (2), $131-7$.

[44] Fagernes, M., and Lingaas, E. (2011).Factors interfering with the microflora on hands: a regression analysis of samples from 465 healthcare workers. Journal of Advanced Nursing, 67(2), 297-307.

[45] Perez-Rodriguez, F., Valero, A., Carrasco, E., Garcia, R.M., and Zurera,G. (2008). Understanding and modelling bacterial transfer to foods: a review. Trends in Food Science \& Technology, 19, 131-144.

[46] Ewen, C.D., \& Todd, (2014). Personal Hygiene and Health (Chapter 28). Food Safety Management, 769-798.

[47] Hood, S. K. \& E. A. Zottola, (1997). Adherence to stainless steel by foodborne microorganisms during growth in model food systems. International Journal of Food Microbiology, 37, 145-153.

[48] Joseph, B., Otta, S. K., \& Karunasagar, I. (2001). Biofilm formation by Salmonella spp. on food contact surfaces and their sensitivity to sanitizers. International Journal of Food Microbiology, 85, 227-236.

[49] Jiménez, S. M., Tiburzi, M. C., Salsi, M. S., Moguilevsky, M. A., \& Pirovani, M. E. (2008). Survival of Salmonella on refrigerated chicken carcasses and subsequent transfer to cutting board. Letters in Applied Microbiology, 48, 687691.

[50] Fernane, F., Morales, A., Carrasco, E., \& García-Gimeno, R. M. (2010). Transfer of Salmonella to ready-to-eat meat products during slicing. In 22nd International ICFMH Symposium Abstract Book (p. 235). Copenhagen, 30.08.201003.09.2010. 